\title{
Role of Biofertilizer and Chemical Fertilizer for Sustainable Onion (Allium cepa L.) Production
}

\author{
V.K. Singh, Amrita Kumari", V.K. Chaudhary and S. Shree
}

Department of Horticulture (Vegetables and Floriculture), Bihar Agricultural University, Sabour -813210, Gujarat, India

*Corresponding author

\section{A B S T R A C T}

The experiment was carried out in the Department of Horticulture (Vegetable and Floriculture), Bihar Agricultural College, sabour to study the role of biofertilizers and chemical fertilizers for onion production. The experiment was laid out in a factorial

\section{Keywords}

Onion,

Azospirillum, VAM, Chemical fertilizers.

Article Info

Accepted:

21 July 2017

Available Online:

10 September 2017 randomized block design, replicated thrice with onion variety Arka Kalyan. The experiment was framed with biofertilizers viz., $\mathrm{M}_{0^{-}}$0, $\mathrm{M}_{1^{-}}$Azospirillum, $\mathrm{M}_{2^{-}}$VAM, $\mathrm{M}_{3^{-}}$ PSB, $\mathrm{M}_{4}$ - Azospirillum $+\mathrm{VAM}$ and $\mathrm{M}_{5}$ - Azospirillum $+\mathrm{PSB}$ and four levels of chemical fertilizers, $\mathrm{F}_{1}-\mathrm{N}_{60} \mathrm{P}_{30} \mathrm{~K}_{40}, \mathrm{~F}_{2^{-}} \mathrm{N}_{90} \mathrm{P}_{45} \mathrm{~K}_{60}, \mathrm{~F}_{3}-\mathrm{N}_{120} \mathrm{P}_{60} \mathrm{~K}_{80}$ and $\mathrm{F}_{4}-\mathrm{N}_{150} \mathrm{P}_{75} \mathrm{~K}_{100}$ having 24 treatment combinations. The results of the experiment showed that the fertility level $\mathrm{F}_{3}$ $\left(\mathrm{N}_{120} \mathrm{P}_{60} \mathrm{~K}_{80}\right.$ ) with inoculation of $\mathrm{M}_{4}$ (Azospirillum $+\mathrm{VAM}$ ) i.e., $\mathrm{M}_{4} \mathrm{~F}_{3}$ produced maximum plant height $(51.96 \mathrm{~cm})$, number of leaves per plant $(11.96)$, leaf length $(45.71 \mathrm{~cm})$, fresh weight of leaves per plant $(32.58 \mathrm{~g})$ as well as yield and its attributing components like bulb length $(5.13 \mathrm{~cm})$, bulb diameter $(5.85 \mathrm{~cm})$, bulb weight $(81.44 \mathrm{~g})$, bulb volume (92.8cc), bulb yield $(467.61 \mathrm{q} / \mathrm{ha})$, dry bulb weight $(45.10 \mathrm{q} / \mathrm{h})$ and total dry weight of plants $(63.92 \mathrm{q} / \mathrm{ha})$ were also achieved by $\mathrm{M}_{4} \mathrm{~F}_{3}$ treatment. However, inoculation of Azospirillum + VAM with seedling treatment as well as soil application at the fertility level of $\mathrm{N}_{90} \mathrm{P}_{45} \mathrm{~K}_{60}$ was the most effective combination for higher net return and $\mathrm{B}$ : $\mathrm{C}$ ratio(3.47) whereas the fertility level $\mathrm{F}_{3}\left(\mathrm{~N}_{120} \mathrm{P}_{60} \mathrm{~K}_{80}\right)$ with inoculation of $\mathrm{M}_{4}$ (Azospirillum $\left.+\mathrm{VAM}\right)$ i.e., $\mathrm{M}_{4} \mathrm{~F}_{3}$ ranked $2^{\text {nd }}$ in merit having $\mathrm{B}: \mathrm{C}$ ratio of 3.36 .

\section{Introduction}

Onion (Allium cepa L.) is considered to be a high value cash crop for India and abroad. It is one of the most important vegetable cum spice crop having various uses in everyday cooking. India is $2^{\text {nd }}$ largest producer next to china. Onion bulbs are rich in minerals like phosphorus, calcium and carbohydrate. It also contains protein and vitamin C. Low productivity of onion may be attributed due to poor management efficiency rather than that in the uncontrollable climatic factors.
Thus, it makes it imperative to make a concerted effort to bridge the gap between potential yield and actual yield harvested by the farmers to make onion cultivation more remunerative through better management strategic of inputs like nutrient management practices and microbial inoculants for better exploitation of yield potentialities. Escalating costs of chemical fertilizers are hampering our way to produce more per unit area. Moreover, excessive use of inorganic 
fertilizer has also resulted in serious damage to our soil and soil resources and to human health too. Biofertilizers are carrier-based preparations containing beneficial microorganisms in viable state intended for seed or soil application. In recent years they have emerged as a promising component of integrated nutrient supply system. They are likely to assume greater significance as a complements or supplements to the chemical fertilizers because of high nutrient turnover, exorbitant cost of fertilizers, soil and environmental protection. Biofertilizers are less expensive, ecofriendly, providing plant hormones and help in sustainable crop production through maintenance of soil productivity (Vijayakumar et al., 2000; Ramakrishnan and Thamizhiniyan, 2004). The use of biofertilizers in combination with chemical fertilizers offers a great opportunity to increase the crop production at less cost (Gunjan et al., 2005). The concept of sustainable agriculture envisages primary emphasis on manipulation and management of biological systems not only to maximize yield but also to stabilize the agro-systems and to minimize industrial input demands which may endure the adverse effect of climate change. Therefore, the experiment was conducted for sustainable production of onion with combine use of biofertilizers and chemical fertilizers.

\section{Materials and Methods}

The experiment was carried out in the Department of Horticulture (Vegetable and Floriculture), Bihar Agricultural College Sabour during rabi season. The experiment was laid out in a factorial randomized block design, replicated thrice with onion variety Arka Kalyan. The treatments comprised of five treatments of biofertilizers $\left(\mathrm{M}_{0^{-}} 0, \mathrm{M}_{1^{-}}\right.$ Azospirillum, $\mathrm{M}_{2^{-}}$VAM, $\mathrm{M}_{3^{-}} \mathrm{PSB}, \mathrm{M}_{4-}$ Azospirillum + VAM and $\mathrm{M}_{5}$ - Azospirillum + PSB) and four levels of chemical fertilizers
(F1- $\mathrm{N}_{60} \mathrm{P}_{30} \mathrm{~K}_{40}, \mathrm{~F}_{2}-\mathrm{N}_{90} \mathrm{P}_{45} \mathrm{~K}_{60}, \mathrm{~F}_{3}-\mathrm{N}_{120} \mathrm{P}_{60} \mathrm{~K}_{80}$ and $\left.\mathrm{F}_{4}-\mathrm{N}_{150} \mathrm{P}_{75} \mathrm{~K}_{100}\right)$. Biofertilizers were used as seedling inoculation as well as soil application. Treatment wise different microbial inoculants at the rate of $10 \mathrm{~g} /$ litre of water were mixed and the roots of uprooted seedlings were dipped for 20 minutes before transplanting. For soil, microbial inoculants were applied at the rate of $6 \mathrm{~kg} / \mathrm{ha}$. As per treatment microbial inoculants and dried F.Y.M in the ratio of 1:20 were mixed thoroughly and mixture was broadcasted and incorporated in the sub-plots.

After application of the microbial inoculants the seedlings allocated with respective microbial inoculants were transplanted at the spacing of $15 \times 10 \mathrm{~cm}$. Full dose of phosphorus $\left(\mathrm{P}_{2} \mathrm{O}_{5}\right)$ as diammonium phosphate and potash $\left(\mathrm{K}_{2} \mathrm{O}\right)$ as murate of potash with $1 / 3^{\text {rd }}$ dose of nitrogen as urea were applied before transplanting of seedlings as basal dressing commensurating with treatments specifications. As per treatment the remaining dose of $\mathrm{N}$ was top dressed in two equal split i.e., one third at 25 days of transplanting and the rest at 50 days after transplanting. Necessary irrigations were given. Gap filling, intercultural operation and plant protection measures were given for the better establishment of crop.

The observations were recorded on vegetative characters such as plant height, number of leaves per plant, fresh weight of leaves per plant, collar thickness, total dry weight of plants and yield attributing characters like bulb length, bulb diameter, bulb weight, bulb volume, dry bulb weight and bulb yield. The statistical analysis of the data noted in all observations was carried out by the method of "Analysis of variance as suggested by Fisher and Yates (1963). Comparison of the treatments was made with the help of critical differences (C.D.). The economics studies of the crop was done by computing the cost of 
cultivation and net profit in rupees per hectare on the basis of the prevailing rate of inputs and output obtained from the local market. Gross return was calculated by multiplying yield ( $\mathrm{q} / \mathrm{ha}$ ) with average selling rate of onion bulbs. The net return (Rs/ha) was computed by subtracting the cost of cultivation from the gross return obtained from the sale of the harvested bulb. The benefit -cost ratio i.e. the net return per rupee investment was obtained by dividing net profit with total cost of cultivation.

\section{Results and Discussion}

The results revealed that the application of microbial inoculant $\mathrm{M}_{4}$ (Azospirillum + VAM) produced maximum plant height $(47.22 \mathrm{~cm})$, number of leaves per plant(10.62), leaf length $(41.54 \mathrm{~cm}), \quad$ collar thickness $(1.79 \mathrm{~cm})$ and fresh weight of leaves/ plant $(29.91 \mathrm{~g})$. This treatment was most outstanding being significantly superior to rest of the biofertilizers used.

This may be due to change in the metabolic activities of the plant and the uptake of water and nutrients. In addition to these, microbial inoculants have ability to produce some growth promoting substances which might have led to enhanced cell division and cell elongation, resulting maximum plant length and highest number of leaves per plant, leaf length, collar thickness and fresh weight of leaves/ plant.

The results in respect of these characters are in complete agreement with the findings of Mahmoud and El-Hefny (1999), Rather et al., (2003) and Jha et al., (2006). It is evident from the data (Table 1) this treatment was also found effective for producing maximum bulb length $(5.16 \mathrm{~cm})$, bulb diameter $(5.32 \mathrm{~cm})$, bulb weight $(74.02 \mathrm{~g})$, bulb volume (84.99 cc), bulb yield (425.12q/ha), dry weight of bulb (41.65q/ha) and total dry weight of plant $(59.11 \mathrm{q} / \mathrm{ha})$ followed by the application of $\mathrm{M}_{5}$ i.e., Azospirillum + PSB. The yield improvement might be due to vigorous habit in terms of plant height, leaf length, number of leaves and collar thickness in plants developed under Azospirillum + VAM or Azospirillum + PSB.

Azospirillum might have fixed higher amount of nitrogen in soil and made available to the plants resulting in better uptake of $\mathrm{N}$ by plants. VAM or PSB would have caused more mobilization and solubilization of insoluble $\mathrm{P}$ in the soil and improve the availability of phosphorus to plants. Better crop due to all these factors which might have helped in increasing photosynthetic rate and more physiological and biochemical activities which in turn, perhaps increased the movement of photosynthates from source to sink. Thus, finally resulted in increasing the yield and yield components. These results are in accordance with the findings of Muthuramalingam et al., (2002), Sule et al., (2002), Rather et al., (2003), Yadav et al., (2005) and Jha et al., (2006).

Growth and yield attributing characters were influenced significantly due to different fertility level. The maximum plant height $(48.17 \mathrm{~cm})$, number of leaves per plant (10.84), leaf length $(42.35 \mathrm{~cm})$, fresh weight of leaves/plant (28.39g), bulb length $(5.26 \mathrm{~cm})$, bulb diameter $(5.42 \mathrm{~cm})$, bulb weight $(75.50 \mathrm{~g})$, bulb volume $(86.27 \mathrm{cc})$, bulb yield $(433.54 \mathrm{q} / \mathrm{ha})$, dry weight of bulb $(42.42 \mathrm{q} / \mathrm{ha})$ and total dry weight of plant $(59.23 \mathrm{q} / \mathrm{ha})$ were obtained at the fertility level $\mathrm{F}_{3} \quad\left(\mathrm{~N}_{120} \mathrm{P}_{60} \mathrm{~K}_{80}\right)$. This level was most outstanding being significantly superior to rest of the fertility levels while maximum collar thickness $(1.78 \mathrm{~cm})$ was associated with fertility level $\mathrm{F}_{2^{-}} \quad \mathrm{N}_{90} \mathrm{P}_{45} \mathrm{~K}_{60}$. Significant increase in bulb yield due to different fertility levels has been reported by Girigowda et al., (2005), Kumar et al., (2006) and Dilruba et al., (2006). 
Table.1 Effect of levels of biofertilizers and chemical fertilizer on growth and yield attributes for sustainable onion production

\begin{tabular}{|c|c|c|c|c|c|c|c|c|c|c|c|c|}
\hline Treatments & $\begin{array}{l}\text { Plant } \\
\text { height } \\
(\mathrm{cm} .)\end{array}$ & $\begin{array}{l}\text { No. of } \\
\text { leaves } \\
\text { /Plant }\end{array}$ & $\begin{array}{l}\text { Leaf } \\
\text { length } \\
(\mathrm{cm} .)\end{array}$ & $\begin{array}{l}\text { Collar } \\
\text { thickness } \\
(\mathrm{cm})\end{array}$ & $\begin{array}{l}\text { Fresh } \\
\text { weight } \\
\text { of } \\
\text { leaves/ } \\
\text { plant } \\
\text { (g) }\end{array}$ & $\begin{array}{l}\text { Bulb } \\
\text { length } \\
(\mathrm{cm})\end{array}$ & $\begin{array}{l}\text { Bulb } \\
\text { diameter } \\
(\mathrm{cm})\end{array}$ & $\begin{array}{l}\text { Bulb } \\
\text { weight } \\
\text { (g) }\end{array}$ & $\begin{array}{l}\text { Bulb } \\
\text { volume } \\
\text { (cc) }\end{array}$ & $\begin{array}{l}\text { Bulb } \\
\text { yield } \\
\text { q/ha }\end{array}$ & $\begin{array}{l}\text { Dry } \\
\text { weight } \\
\text { of bulb } \\
\text { (q/ha) }\end{array}$ & $\begin{array}{l}\text { Total } \\
\text { dry } \\
\text { weight } \\
\text { of plant } \\
(q / h)\end{array}$ \\
\hline \multicolumn{13}{|c|}{ Levels of Biofertilizer } \\
\hline $\begin{array}{l}\mathrm{M}_{0} \text {-No Bio- } \\
\text { fertilizer }\end{array}$ & 35.37 & 7.96 & 31.24 & 1.50 & 19.41 & 3.89 & 3.98 & 55.44 & 65.61 & 318.36 & 32.31 & 44.60 \\
\hline $\mathrm{M}_{1}$ Azospirillum & 44.64 & 10.04 & 39.33 & 1.65 & 26.59 & 4.86 & 5.02 & 69.97 & 81.49 & 401.73 & 39.82 & 55.66 \\
\hline $\mathrm{M}_{2-} \mathrm{VAM}$ & 43.96 & 9.89 & 38.68 & 1.63 & 25.49 & 4.79 & 4.95 & 68.90 & 80.59 & 395.68 & 39.55 & 55.20 \\
\hline $\mathrm{M}_{3}-\mathrm{PSB}$ & 42.11 & 9.75 & 38.10 & 1.63 & 24.47 & 4.72 & 4.88 & 67.96 & 78.06 & 390.22 & 38.70 & 53.36 \\
\hline $\begin{array}{l}\mathrm{M}_{4} \text {-Azospirillum } \\
+\mathrm{VAM}\end{array}$ & 47.22 & 10.62 & 41.54 & 1.79 & 29.91 & 5.16 & 5.32 & 74.02 & 84.99 & 425.12 & 41.65 & 59.11 \\
\hline $\begin{array}{l}\mathrm{M}_{5} \text {-Azospirillum } \\
+\mathrm{PSB}\end{array}$ & 45.22 & 10.26 & 40.13 & 1.76 & 27.88 & 4.97 & 5.14 & 71.50 & 82.34 & 410.54 & 40.60 & 57.21 \\
\hline $\mathrm{CD}$ at $5 \%$ & 1.64 & 0.35 & 1.27 & 0.06 & 0.97 & 0.20 & 0.16 & 2.42 & 2.49 & 15.52 & 1.45 & 1.88 \\
\hline \multicolumn{13}{|c|}{ Levels of Chemical fertilizer } \\
\hline $\mathrm{F}_{1}-\mathrm{N}_{60} \mathrm{P}_{30} \mathrm{~K}_{40}$ & 33.55 & 7.55 & 29.64 & 1.42 & 19.82 & 3.65 & 3.78 & 52.57 & 64.08 & 301.93 & 31.62 & 44.19 \\
\hline $\mathrm{F}_{2}-\mathrm{N}_{90} \mathrm{P}_{45} \mathrm{~K}_{60}$ & 45.10 & 10.33 & 40.41 & 1.78 & 27.14 & 5.03 & 5.17 & 72.00 & 82.76 & 413.39 & 40.55 & 56.76 \\
\hline $\mathrm{F}_{3}-\mathrm{N}_{120} \mathrm{P}_{60} \mathrm{~K}_{80}$ & 48.17 & 10.84 & 42.35 & 1.72 & 28.39 & 5.26 & 5.42 & 75.50 & 86.27 & 433.54 & 42.42 & 59.23 \\
\hline $\mathrm{F}_{4}-\mathrm{N}_{150} \mathrm{P}_{75} \mathrm{~K}_{100}$ & 45.80 & 10.30 & 40.28 & 1.72 & 27.16 & 4.99 & 5.16 & 71.78 & 82.28 & 412.24 & 40.50 & 56.59 \\
\hline $\mathrm{CD}$ at $5 \%$ & 1.34 & 0.28 & 1.05 & 0.05 & 0.80 & 0.16 & 0.13 & 2.00 & 2.06 & 12.80 & 1.20 & 1.55 \\
\hline
\end{tabular}


Table.2 Combined effect of biofertilizers and chemical fertilizer on growth and yield attributes for onion production

\begin{tabular}{|c|c|c|c|c|c|c|c|c|c|c|c|c|c|c|}
\hline $\mathrm{MXF}$ & $\begin{array}{l}\text { Plant } \\
\text { height } \\
(\mathrm{cm} .)\end{array}$ & $\begin{array}{l}\text { No. of } \\
\text { leaves } \\
\text { /Plant }\end{array}$ & $\begin{array}{l}\text { Leaf } \\
\text { length } \\
(\mathrm{cm} .)\end{array}$ & $\begin{array}{l}\text { Collar } \\
\text { thickness }\end{array}$ & $\begin{array}{l}\text { Fresh } \\
\text { weight } \\
\text { of } \\
\text { leaves/ } \\
\text { plant (g) }\end{array}$ & $\begin{array}{l}\text { Bulb } \\
\text { length } \\
(\mathrm{cm})\end{array}$ & $\begin{array}{l}\text { Bulb } \\
\text { diameter } \\
(\mathrm{cm})\end{array}$ & $\begin{array}{l}\text { Bulb } \\
\text { weight } \\
\text { (g) }\end{array}$ & $\begin{array}{l}\text { Bulb } \\
\text { volume } \\
\text { (cc) }\end{array}$ & $\begin{array}{l}\text { Bulb } \\
\text { yield } \\
\text { (q/ha) }\end{array}$ & $\begin{array}{l}\text { Dry } \\
\text { weight } \\
\text { of bulb } \\
\text { (q/ha) }\end{array}$ & $\begin{array}{l}\text { Total dry } \\
\text { weight } \\
\text { of plant } \\
(\mathrm{q} / \mathrm{h})\end{array}$ & $\begin{array}{l}\text { Net } \\
\text { Income } \\
\text { (Rs.) }\end{array}$ & $\begin{array}{l}\text { B:C } \\
\text { Ratio }\end{array}$ \\
\hline $\mathrm{M}_{0} \mathrm{~F}_{1}$ & 23.38 & 5.26 & 21.06 & 1.26 & 12.82 & 2.55 & 2.63 & 36.63 & 45.83 & 210.44 & 23.20 & 32.09 & 43622 & 1.08 \\
\hline $\mathrm{M}_{0} \mathrm{~F}_{2}$ & 31.57 & 7.10 & 27.77 & 1.48 & 17.33 & 3.61 & 3.55 & 49.48 & 60.35 & 284.11 & 28.72 & 39.67 & 72828 & 1.79 \\
\hline $\mathrm{M}_{0} \mathrm{~F}_{3}$ & 42.53 & 9.57 & 37.42 & 1.58 & 23.36 & 4.63 & 4.78 & 66.66 & 77.21 & 382.77 & 38.17 & 52.68 & 111086 & 2.64 \\
\hline $\mathrm{M}_{0} \mathrm{~F}_{4}$ & 44.02 & 9.91 & 38.73 & 1.71 & 24.14 & 4.79 & 4.95 & 68.99 & 79.06 & 396.14 & 39.16 & 53.98 & 115529 & 2.69 \\
\hline $\mathrm{M}_{1} \mathrm{~F}_{1}$ & 35.30 & 7.94 & 31.31 & 1.36 & 21.02 & 3.84 & 3.97 & 55.31 & 67.66 & 317.58 & 32.87 & 45.73 & 85546 & 2.07 \\
\hline $\mathrm{M}_{1} \mathrm{~F}_{2}$ & 48.37 & 10.89 & 42.55 & 1.82 & 28.81 & 5.27 & 5.44 & 75.81 & 87.75 & 435.28 & 42.81 & 59.97 & 132364 & 3.17 \\
\hline $\mathrm{M}_{1} \mathrm{~F}_{3}$ & 48.63 & 10.95 & 42.79 & 1.68 & 28.97 & 5.30 & 5.47 & 76.24 & 86.90 & 437.75 & 42.61 & 59.58 & 132148 & 3.08 \\
\hline $\mathrm{M}_{1} \mathrm{~F}_{4}$ & 46.27 & 10.41 & 40.69 & 1.76 & 27.56 & 5.04 & 5.21 & 72.51 & 83.66 & 416.33 & 40.99 & 57.36 & 122757 & 2.80 \\
\hline $\mathrm{M}_{2} \mathrm{~F}_{1}$ & 34.50 & 7.76 & 30.35 & 1.34 & 19.99 & 3.76 & 3.88 & 54.02 & 66.38 & 310.46 & 32.40 & 45.39 & 82700 & 1.99 \\
\hline $\mathrm{M}_{2} \mathrm{~F}_{2}$ & 47.72 & 10.74 & 41.98 & 1.81 & 27.67 & 5.20 & 5.37 & 74.79 & 87.76 & 429.44 & 42.60 & 59.35 & 130028 & 3.12 \\
\hline $\mathrm{M}_{2} \mathrm{~F}_{3}$ & 48.28 & 10.88 & 42.47 & 1.68 & 28.00 & 5.26 & 5.43 & 75.67 & 86.45 & 434.47 & 42.97 & 59.90 & 130838 & 3.05 \\
\hline $\mathrm{M}_{2} \mathrm{~F}_{4}$ & 45.37 & 10.21 & 39.92 & 1.69 & 26.31 & 4.94 & 5.11 & 71.12 & 81.79 & 408.36 & 40.26 & 56.16 & 119427 & 2.73 \\
\hline $\mathrm{M}_{3} \mathrm{~F}_{1}$ & 33.95 & 7.64 & 29.87 & 1.43 & 19.16 & 3.70 & 3.82 & 53.22 & 64.20 & 305.53 & 31.79 & 43.27 & 80726 & 1.99 \\
\hline $\mathrm{M}_{3} \mathrm{~F}_{2}$ & 41.95 & 10.57 & 41.30 & 1.78 & 26.49 & 5.11 & 5.28 & 73.59 & 82.71 & 422.52 & 41.34 & 57.35 & 127262 & 3.05 \\
\hline $\mathrm{M}_{3} \mathrm{~F}_{3}$ & 48.05 & 10.79 & 42.09 & 1.67 & 27.11 & 5.23 & 5.41 & 75.31 & 85.62 & 432.42 & 42.55 & 58.58 & 130016 & 3.03 \\
\hline $\mathrm{M}_{3} \mathrm{~F}_{4}$ & 44.49 & 10.01 & 39.14 & 1.66 & 25.10 & 4.84 & 5.01 & 69.73 & 79.70 & 400.41 & 39.14 & 54.24 & 116307 & 2.66 \\
\hline $\mathrm{M}_{4} \mathrm{~F}_{1}$ & 37.40 & 8.42 & 32.90 & 1.59 & 23.44 & 4.07 & 4.21 & 58.61 & 71.24 & 336.55 & 34.56 & 49.23 & 93136 & 2.25 \\
\hline $\mathrm{M}_{4} \mathrm{~F}_{2}$ & 51.77 & 11.65 & 45.55 & 1.91 & 32.46 & 5.64 & 5.83 & 81.15 & 90.34 & 465.94 & 44.85 & 63.60 & 194630 & 3.47 \\
\hline $\mathrm{M}_{4} \mathrm{~F}_{3}$ & 51.96 & 11.69 & 45.71 & 1.88 & 32.58 & 5.73 & 5.85 & 81.44 & 92.80 & 467.61 & 45.10 & 63.92 & 144092 & 3.36 \\
\hline $\mathrm{M}_{4} \mathrm{~F}_{4}$ & 47.77 & 10.75 & 42.03 & 1.78 & 31.17 & 5.20 & 5.38 & 74.87 & 85.60 & 430.40 & 42.08 & 59.72 & 128305 & 2.93 \\
\hline $\mathrm{M}_{5} \mathrm{~F}_{1}$ & 36.78 & 8.28 & 32.36 & 1.58 & 22.48 & 4.01 & 4.14 & 57.65 & 69.20 & 331.01 & 34.90 & 49.42 & 90918 & 2.19 \\
\hline $\mathrm{M}_{5} \mathrm{~F}_{2}$ & 49.23 & 11.08 & 43.31 & 1.88 & 30.09 & 5.36 & 5.54 & 77.17 & 87.67 & 443.07 & 42.98 & 60.60 & 135482 & 3.25 \\
\hline $\mathrm{M}_{5} \mathrm{~F}_{3}$ & 49.58 & 11.16 & 43.63 & 1.82 & 30.31 & 5.40 & 5.58 & 77.72 & 88.64 & 446.25 & 43.13 & 60.72 & 135550 & 3.16 \\
\hline $\mathrm{M}_{5} \mathrm{~F}_{4}$ & 46.87 & 10.54 & 41.21 & 1.76 & 28.66 & 5.10 & 5.28 & 73.47 & 83.87 & 421.84 & 41.38 & 58.09 & 124881 & 2.85 \\
\hline $\mathrm{CD}$ at $5 \%$ & 3.24 & 0.66 & 2.41 & 0.11 & 1.86 & 0.38 & 0.31 & 4.61 & 4.86 & 29.52 & 2.76 & 3.59 & 8879.05 & 0.16 \\
\hline
\end{tabular}


The interaction effect between different levels of inorganic fertilizers and biofertilizers were found to be quite superior to their sole application. Among the treatment combinations $\mathrm{M}_{4} \mathrm{~F}_{3}$ i.e., application of higher dosages of inorganic fertilizers i.e., $\mathrm{F}_{3}\left(\mathrm{~N}_{120} \mathrm{P}_{60} \mathrm{~K}_{80}\right)$ along with inoculation of biofertilizers $\mathrm{M}_{4}$ (Azospirillum + VAM) exhibited significantly highest values of plant height (51.96 $\mathrm{cm})$,number of leaves per plant(11.69), leaf length $(45.71 \mathrm{~cm})$, fresh weight of leaves/plant (32.58 g),bulb length $(5.73 \quad \mathrm{~cm})$, bulb diameter(5.85 $\mathrm{cm})$,bulb weight $(81.44 \mathrm{~g})$, bulb volume $(92.80 \mathrm{cc})$, bulb yield $(467.61 \mathrm{q} / \mathrm{ha})$, dry weight of bulb(45.10 q/ha) and total dry weight of plant $63.92 \mathrm{q} / \mathrm{ha}$ ). This may be due to the profuse vegetative growth induced by higher dose of chemical fertilizers and application of microbial inoculant $\mathrm{M}_{4}$ (Azospirillum $+\mathrm{VAM}$ ). This ultimately may increase the photosynthetic assimilation. All these physiological activities brought about increase in bulb size and bulb weight as the weight of individual bulb increased it reflected positively on the total bulb yield. The results are closely in consonance with the finding of Singh and Singh (2002), ElShaikh (2005), Jayathilake et al., (2002), Singh and Pandey (2006) and Yogita and Ram (2012).

\section{Economics}

The interaction between biofertilizers and inorganic fertilizers was found to be highly significant, meaning thereby that different fertility levels influenced the biofertilizers behaviour and vice-versa. The net profit per hectare ranged from Rs.43,622.00 to Rs. 1, 94,630.00 (Table 2). The highest net profit of Rs.1,94,630.00/ha with the maximum benefitcost ratio of 3.47 were obtained with the application of microbial inoculant $\mathrm{M}_{4}$ (Azospirillum $+\mathrm{VAM})$ at the fertility level of $\mathrm{F}_{2}$ $\left(\mathrm{N}_{90} \mathrm{P}_{45} \mathrm{~K}_{60}\right)$ i.e., $\mathrm{M}_{4} \mathrm{~F}_{2}$. However, the fertility level $\mathrm{F}_{3}\left(\mathrm{~N}_{120} \mathrm{P}_{60} \mathrm{~K}_{80}\right)$ with inoculation of $\mathrm{M}_{4}$ (Azospirillum $+\mathrm{VAM}$ ) i.e., $\mathrm{M}_{4} \mathrm{~F}_{3}$ ranked $2^{\text {nd }}$ in merit having net profit (Rs.1,44,092.00) with higher $\mathrm{B}: \mathrm{C}$ ratio of 3.36 . The lowest fertility level of $\mathrm{F}_{1}\left(\mathrm{~N}_{60} \mathrm{P}_{30} \mathrm{~K}_{40}\right)$ in the absence of biofertilizers i.e., $\mathrm{M}_{0} \mathrm{~F}_{1}$ produced the minimum net profit (Rs.43,622. 00/ha) with B: C ratio (1:08).

Application of higher dosages of inorganic fertilizers i.e. $\mathrm{F}_{3} \quad\left(\mathrm{~N}_{120} \mathrm{P}_{60} \mathrm{~K}_{80}\right)$ along with inoculation of biofertilizers $\mathrm{M}_{4}$ (Azospirillum + VAM) influenced the growth as well as yield contributing characters and bulb yield significantly in comparison to the remaining treatment combinations. However, the inoculation of Azospirillum + VAM with seedlings as well as soil application at the fertility level of $\mathrm{N}_{90} \mathrm{P}_{45} \mathrm{~K}_{60}$ was the most effective combination for higher $\mathrm{B}$ : $\mathrm{C}$ ratio and net return. Hence, the use and management of natural resources in sustainable agriculture, the microbial fertilizers hold vast potential for the future.

\section{Acknowledgement}

The authors acknowledge, Chairman, Department of Horticulture, (Vegetables and Floriculture), Bihar Agricultural College, Bihar Agricultural University, Sabour, India for providing all the required infrastructure and facilities for the present work and those scientists whose published works has been cited in the text of this research paper

\section{References}

Dilruba, S., Alam M.M., Rahman M.A., and Hasan M F 2006. Influence of nitrogen and potassium on yield contributing bulb traits of onion. International J. Agril. Res. 1 (1): 85-90.

El- Shaikh and K.A.A., 2005. Growth and yield of onion as affected by biofertilization, application of nitrogen and phosphorus fertilizers under South Valley Conditions. Assiut J. Agril. Sci. 36 (1): 37-50.

Fisher, R.A., and Yates F 1963. Statistical tables for Biological, Agricultural and Medical Research, Long Man Group Limited, London. Sixth Edition.

Girigowda, J.R., Narasegowda N C and Krishna H C 2005. Effect of fertilizer levels on uptake of primary nutrients and bulb yield 
of on hybrids. Mysore J. Agril. Sci. 39 (4): 557-560

Gunjan Aswani, Paliwal R and Saralia D K 2005. Effect of nitrogen and biofertilizers on yield and quality of rabi onion (Allium cepa L.) cv. Puna Red. Agril. Sci. Digest, 25 (2): 124-126.

Jayathilake, P.K.S., Reddy I P, Srihari D, Neeraja G and Reddy R 2002. Effect of nutrient management on growth, yield and yield attributes of rabi onion (Allium cepa L.). Vegetable Science. 29(2): 184185.

Jha, A.K., Pal Netra, Saxena A.K., Singh Dhyan and Jha G K 2006. Coinoculation effect of VAM and PGR on growth and yield of onion. Ind. J. Hort. 63 (1): 44-47.

Kumar Susheel, Tiwari Sushant C P and Singh Vijay 2006. Bulb yield and quality of onion (Allium cepa L.) as affected by application rates of nitrogen and potassium fertilizer. Agril. Sci. Digest. 26 (1): 11-14.

Mahmoud, H.A.F., and El Hefny E M 1999. Effect of mycorrhizal infection and phosphorus concentrations on onion plant. Annals Agril. Sci., Moshtohor. 37 (3): 1805-1817.

Muthuramalingam, S., Muthuvel I, Sankar V and Thamburaj S 2002. Influence of plant density and applied nutrients on uptake of NPK seed propagated aggregatum onion (Allium cepa L. Var aggregatum) Gananamedu Local type. News Letter National Horticultural Research and Development Foundation.22 (2): 1-16.

Ramakrishnan, K., and Thamizhiniya P 2004. The effect of NPK fer tilizer and AM fungi on the yield and quality characters of cotton (Gossypium hirsutum L.) var. LRA 5166. Plant Arch., 9 (1): 8788.

Rather, S., Ahmed A N and Chattoo M A 2003. Response of onion to microbial inoculation and chemical nitrogen. Haryana J. of Horticultural Sciences. 32 (3/4): 270-271.

Singh Vinay, and Pandey Manoj 2006. Effect of integrated nutrient management on yield and nutrient uptake by onion and on soil fertility. J. Ind. Society of Soil Science. 54 (3): 365-367.

Singh, A., Singh S P and Singh B O 2002. Effect of VAM and inorganic fertilizers on growth and yield of onion (Allium cepa L.). Vegetable Science. 29 (1): 4042.

Sule, S.R., Rahane R K and Shinde V A 2002. Impact of biofertilizers on productivity of field crops. J. Maharashtra Agril. Univ. 27 (2): 180-181.

Vijayakumar, B.S., P V Bhiravamurthy and Anand M C 2000. VAM fungi association in Lycoperiscon esculentum L. grown in semi-arid tropical soils of Puttaparthy, A.P.J. Ecobiol., 12 (1): 73-74

Yadav Dashrath, Prasad V M and. Gujar K D 2005. Effect of different biofertilizers in association with phosphorus on growth and yield of onion (Allium cepa L.), a white onion var. JNDWO. New Agriculturist. 16 (1/2): 87-89.

Yogita and Ram R B 2012. Interaction effect of chemical and bio-fertilizers on growth and yield of onion (Allium cepa L.). Hort Flora Research Spectrum, 1(3): 239-243

\section{How to cite this article:}

Singh, V.K., Amrita Kumari, V.K. Chaudhary and Shree, S. 2017. Role of Biofertilizer and Chemical Fertilizer for Sustainable Onion (Allium cepa L.) Production. Int.J.Curr.Microbiol.App.Sci. 6(9): 2034-2040. doi: https://doi.org/10.20546/ijcmas.2017.609.250 